\title{
文京区駒込の寺地の変遷 \\ TRANSITION OF THE BUDDHIST TEMPLE AREA IN THE KOMAGOME DISTRICT, BUNKYO
}

\author{
渡 邊 美 樹* \\ Miki WATANABE
}

\begin{abstract}
This study uses historical maps and data to research the Buddhist temple area in Komagome. The temple and graveyard areas of the Edo, Early-Meiji Period, Beginning of Taisho Period and the present day are layered on a map, and the overlapping images are analyzed. As a result of the analysis, the following findings are observed:

1. In the Edo Period, many temples were transferred from the neighboring areas, for example, Kanda, Yushima and Hongo. Of these, nine temples' were using the Rinso-in's territory.

2. After land requisition in the early Meiji Period, in almost all cases, less than half of the bestowed land was authorized as a precinct temple area. Leased or taxed land in the Edo Period were authorized as a private land.

3. Some of the temple area was disposed and returned as private land due to the self-clearing petition appealed by the superior of the temple.

4. By the end of the Meiji Period, many temple areas, inside and outside the precinct were disposed. In many cases, graveyards remained on the original temple area.

5. The shape of the main street in the Edo Period can be seen in this area, and that of the town house block inherited from the Edo Period can be seen in some places. On the other hand, the high-rise apartment, located along the main street, overlooks the cemetery from the balcony of the apartment.
\end{abstract}

Keywords: Komagome, Hongo, Buddhist temple territory, Temple area, Precincts, Transition 駒込, 本郷、寺院領地, 寺地, 境内, 変遷

1.はじめに

\section{1-(1) 研究の背景と目的}

本研究は、享保年間の初頭（1720 年ごろ）までに江戸の寺町が形 成された概要を把握した上で、明治初期の寺社領上地を経た後、現 在までの寺地と墓地領域の変化を検証し、江戸外縁部の寺地の形成 と変容について考察することを目的としている。高密化を続け、一 部では大規模な再開発計画が繰り広げられる都市の中で、現在もな お維持されている寺地と墓地は、江戸期からの元の地点を継承する 遺構であるとともに、今後も貴重なオープンスペースとして維持さ れる可能性がある。

筆者はこれまで既に、現在寺町の様相が保たれてる台東区谷中地 区と、震災後の区画整理や土地運用によって寺地が極端に整形・縮 小した台東区西浅草に焦点をあて、現在までの各地区の寺地の変遷 についての考察を行なった $\left.{ }^{1 ）} 2\right)$ 。前稿でも述べたとおり、江戸寺院 の起立と移転、寺町の形成に関しては、鈴木、日塔両氏による詳細 な研究報告がなされており ${ }^{3)}$ 4)、江戸寺院と寺地の存在形態について は伊藤氏により ${ }^{5)}$ 、江戸の都市之社会構成については吉田氏による 調查研究成果がまとめられている ${ }^{6)}$ 。さらに寺院境内の変化と建築 あるいは寺町の変化については増上寺 ${ }^{7)}$ 、三田寺町 ${ }^{8)}$ における図式
的分析を含めた研究報告がなされ、寛永寺および浅草寺については 光井氏によって、寺院の経済機構を含めた詳細な論文資料がまとめ られている ${ }^{9)}$ 。本研究においては、それらの研究成果を参照しながら、 特定の地区を対象として、時代ごとの寺地領域を地図上に重䄈るこ とによって同じ地点での時代による変化を比較検討し、その特徴に ついて考察する。

1-（2）谷中、西浅草地区についての前稿研究と本稿の位置づけ

前稿、台東区谷中地区の寺地の変遷については、江戸期から寺院 数と寺地の極端な減少が無い理由として、江戸（墨引き）の外縁で あり中心部からの開発が及ばなかったこと、墓地を伴う寺院が多く 墓地の移動が困難であったと共に、官有墓地は実際に寺院が管理し たため実質上は寺地が確保されたこと、震災と戦災からまぬがれ、 大規模な区画整理による敷地の分断や縮小がなかった点などを述べ た。台東区西浅草の寺地については、江戸元禄期に寺地であった箇 所が安政期には一部町人地となっており、この地区では町人地拡大 の影響が見られること、大正期の寺地の地籍には敷地全体が官有地 の寺院や個人名義の寺地および墓地があり、谷中地区の大正期の地 籍種別とは相違が見られること、震災復興以後、区画整理による敷 地形状の変化と墓地の特設化による墓地領域の縮小が行われ、特に 


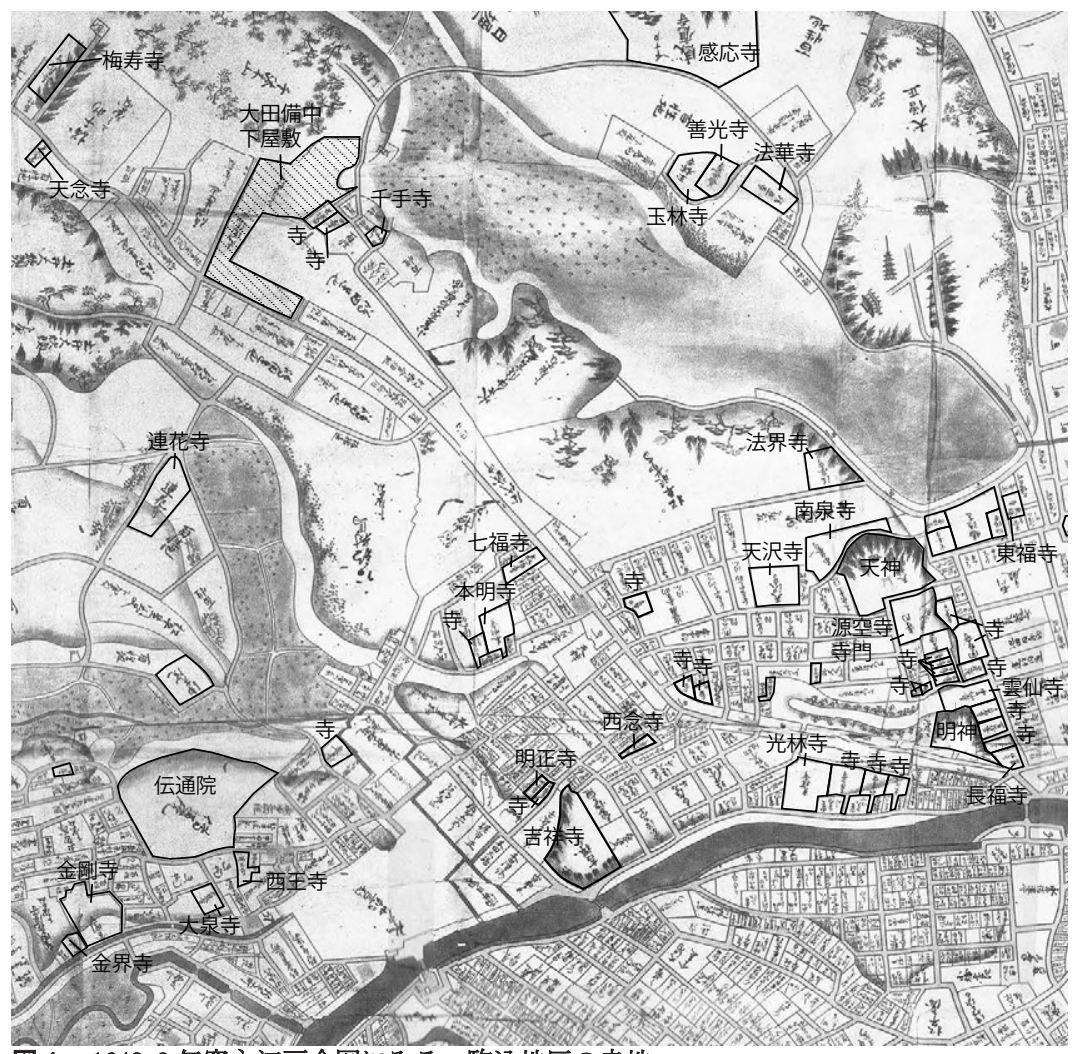

図 $11642-3$ 年寛永江戸全図にみる、駒込地区の寺地

昭和以後道路沿い用地の運用が急速に高まったため、現況では街区 の中央に寺地が残存する寺院が数多いことを述べた。

本稿においては、江戸期に武家地、寺社地と町人地が入り混じり、 さらには農地との境界領域でもあった文京区駒込地区に着目し、本 地区への寺院の移転経緯を概観した上で、明治以降の寺地の変遷に ついての特徴を探る。

\section{2. 江戸期寺院の起立と移転}

\section{2-（1）対象地区について}

本稿で対象とする駒込地区は、江戸時代の五街道のひとつ、旧中 山道が岩槻街道（日光御成道）と分岐する「駒込追分」から北へ吉 祥寺まで、東へは明治初期江戸府 15 区の小石川区との境界まで、西 一本郷区駒込千駄木町までの領域とする。明治期は本郷区に属し、 現在の向ヶ丘、千駄木、本駒込の一部である。駒込追分の南には「本 郷は兼康までは江戸のうち」とうたわれた「かねやす」がある。追 分の一里塚は日本橋から一里下った目印となっており、旅人の休㓤 場所であったという。安政 3 年重叔地図をみると*1、対象地区の中 央に位置する駒込浅嘉町から東へ伸びる四軒寺町通りを下り、三崎 坂を登れば谷中の寺町、白山権現を経由して南西へ下れば伝通院を 核とする小石川の寺町に通じる。一方で、岩槻街道と旧中山道に挟 まれた領域は、江戸後期までに街道沿いに御用地と町人地があり、 寺町と町人地の間には水戸徳川家、太田家、小笠原家をはじめとす る広大な武家地があり、所々に農地が点在する。さらに北部は千駄 木御林が広がるといった、御用地、武家地、寺社地、町人地、農地 が混在する江戸外縁の地区であった。

\section{2-（2）諸資料と古地図による寺院の起立と移転}

寺町書上 ${ }^{10)}$ に記載されている寺院をピックアップすると、対象範

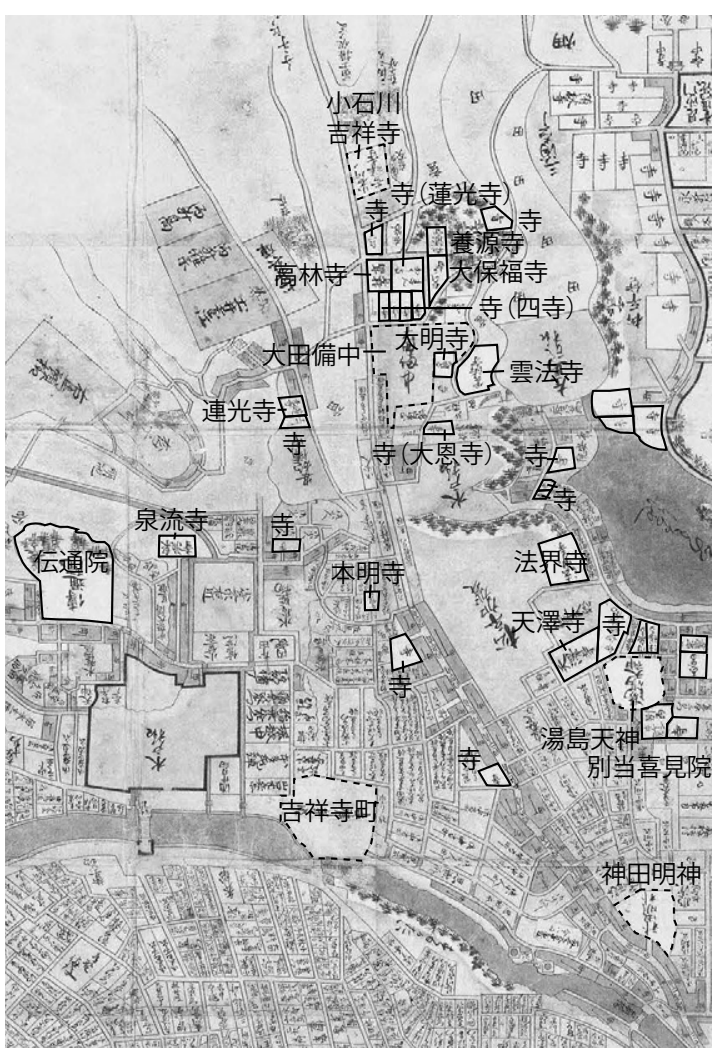

図 2 1657-8 年明暦江戸大絵図にみる、駒込地区の寺地
囲には表 -1 に示寸 46 ケ寺がある。ここに、御府内寺社備考 ${ }^{11)}$ 、寺 院明細帳 ${ }^{12)}$ 、本郷の寺院 ${ }^{13)}$ などの資料から、これらの宗派、寺格、 起立・移転年代、移転前の所在地などの基本事項をまとめた。宗派 の内わけは天台宗 4 ケ寺、浄土宗 18 ケ寺、浄土真宗 5 ケ寺、日蓮宗 6 ケ 寺、曹洞宗 8 ケ寺、臨済宗 5 ケ寺となっており、浄土宗の寺院が数多い。 さらに諸資料によって起立や移転の要因を検討すると、現在の場所 に起立したとわかっている寺院は 6 ケ寺で、そのうち日蓮宗浩妙寺 （番号 41）は太田家屋敷内に起立した寺院である。太田家屋敷内には 同じく日蓮宗長元寺（番号 38）が起立しており、後にごく近隣の街 道沿いに移転している。寺院の移転元をみると、本郷内からの移転 が 9 ケ寺、根津・湯島からが 13 ケ寺、神田・御茶ノ水からが 8 ケ寺 など、ほとんどが近隣の地区からの移転である。中でも、1648 年に 神田の寺地が御用地となったため駒込一の移転を命ぜられた 5 ケ寺 のなかで、浄土宗 4 ヶ寺 (13 栄松院、14 光源寺、15 瑞泰寺、 16 清 林寺）は駒込四軒寺町を形成し、現存している。一方 1657 (明暦 3) 年明暦大火後に移転した寺院は 13 ヶ寺あり、そのうち本郷・湯島か ら 10 ケ寺、神田・御茶ノ水からが 3 ケ寺ある。続いて 1683 (天和 3 ) 年振袖火事後に移転した寺院は 6 ケ寺あり、うち 4 ケ寺が湯島から の移転となっている。これら寺院の移転と寺町の形成過程を古地図 により確認すると、寛永江戸全図（図 1）*2では、この地区に 11 浄 土宗天然寺と現在の吉祥寺北に梅寿寺、太田家屋敷近隣に 2 ケ寺が あり、御茶ノ水には 24 曹洞宗吉祥寺が、神田、湯島には駒込へ移転 する前の寺地がまとまった箇所に確認できる。この時点でこの地区 には、街道沿いに御用地と小笠原家、水戸家、土井家などの広大な 武家地がある。また太田家北側は武家下屋敷（名称不明）、千駄木山 とあり所々に百姓地が点在している。明暦江戸大絵図(図 2)*3では、 吉祥寺が既に移転して元地は吉祥寺町となっており、神田と湯島の 
表 1 駒込地区の寺院の起立・移転と寺地の種別

\begin{tabular}{|c|c|c|c|c|c|c|c|c|c|c|c|c|}
\hline 番号 & 記号 & $\begin{array}{l}\text { 寺社書上 } \\
\text { 細目 }\end{array}$ & 宗 & 場所 & 移転前 & 起立/移転 & 現在地 & 外移転 & $\begin{array}{l}1826 \text { (文政9)年 } \\
\text { 御府内寺社備考 } \\
\end{array}$ & $\begin{array}{l}1877 \text { (明治 10) } \\
\text { 境内 }\end{array}$ & $\begin{array}{r}\text { )年寺院明細帳 } \\
\text { 境外 } \\
\end{array}$ & 寺格·寺中 \\
\hline$\overline{c 1}$ & $\overline{0}$ & 定泉寺 & 浄土 & 駒込浅嘉町 & 本郷弓町 & 1615 & 1657 & & 择領地1260坪 & 官981坪 & 层畑224坪 & 京都知恩院 \\
\hline 2 & - & 大運寺 & 浄土 & 駒込浅嘉町 & 現在地 & 1627 & & & $\begin{array}{l}\text { 麟祥院古跡年貢地 } 192 \text { 坪、 } \\
\text { 外二283坪余借地古跡 }\end{array}$ & 民726坪 & 民畑203坪 & 浅草幡随院 \\
\hline 3 & - & 蓮光寺 & 浄土 & 駒込浅嘉町 & 湯島妻恋坂 & 1601 & 1657 & & 拝領地2918坪 & 官1116坪 & 民186坪 & 京都知恩院 \\
\hline 4 & (0) & 願行寺 & 浄土 & 駒込片町 & 品川、馬喰町 & $1494 、 1657$ & 1684 & & 择領地1300坪 & 官583坪 & & 京都知恩院 \\
\hline 5 & - & 潮泉寺 & 浄土 & 駒込片町 & 本郷丸山 & 1609 & 1657 & & $\begin{array}{l}\text { 拝領地134坪年貢地167坪 }+ \\
\text { 門前40坪 }\end{array}$ & 官145坪民164坪 & 民40坪 & 芝增上寺 \\
\hline 6 & & 十方寺 & 浄土 & 駒込有町 & 根津 & 1615 & 1662 & & $\begin{array}{l}\text { 1370坪除地内855坪年貢地 } \\
\text { 515坪天澤寺 (麟祥院) 領 }\end{array}$ & 民553坪 & & 下谷源立寺 \\
\hline 7 & (2) & 専念寺 & 浄土 & 駒込千駄木町 & 神田水車、湯島天神下 & 1600,1617 & 1683 & & 拝領地 & 官209坪 & 民139坪、願中 & 京都知恩院 \\
\hline 9 & - & 天栄寺 & 浄土 & 駒込土物店 & 本郷丸山、菊坂 & 1617 & 大火後 & & 择領地1065坪 & 官562坪 & & 京都知恩院 \\
\hline 10 & - & 德性寺 & 浄土 & 駒込土物店新道 & 湯島妻恋坂 & 1616 & 1659 & & 拝領地374坪 & 官178坪 & & 本所霊山寺 \\
\hline 11 & घ & 天然寺 & 浄土 & 駒込富士前町 & 現在地 & 1645 & & & 古跡除地756坪 & 官1009坪 & 民798坪 & 浅草聖德寺 \\
\hline 12 & & 正行寺 & 浄土 & 駒込三ヶ家町 & 湯島 & 1605 & 1682 & & $\begin{array}{l}\text { 古跡拝領地 } \\
\text { 252坪 } 625 \text { 坪内門前 }\end{array}$ & 官1012坪 & & 芝增上寺 \\
\hline 13 & $\square$ & 栄松院 & 浄土 & 駒込四軒寺町 & 神田明神下 & 1589 & 1648 & & $\begin{array}{l}\text { 拝領地 1080坪持添年貢地 } \\
\text { 139坪 }\end{array}$ & 官491坪 & 民宅地173坪 & 京都知恩院 \\
\hline 14 & $\square$ & 光源寺 & 浄土 & 駒込四軒寺町 & 神田四軒町 & 1589 & 1648 & & 拝領地 1755 坪 & 官1627坪 & 畑127坪 & 深川本誓寺 \\
\hline 15 & $\square$ & 瑞泰寺 & 浄土 & 駒込四軒寺町 & 神田明神下 & 1589 & 1648 & & $\begin{array}{l}\text { 拝領地 1295坪持添年貢地 } \\
\text { 250坪 }\end{array}$ & 官677坪 & 民202坪 & 京都知恩院 \\
\hline 17 & & 浄心寺 & 浄土 & 駒込追分町 & 湯島妻恋坂 & 1682 & 不詳 & & $\begin{array}{l}\text { 古跡拝領地792坪年貢地 } \\
\text { 648坪麟祥院借地417坪持 } \\
\text { 添地 } 375 \text { 坪 }\end{array}$ & 民556坪 & & 芝增上寺 \\
\hline 18 & (2) & 常德寺 & 浄土 & 下駒込村 & 湯島天神切通し & 1630 & 1683 & & 麟祥院領古跡年貢地 585 坪 & & & 京都知恩院 \\
\hline 19 & & 専西寺 & 浄土真 & 駒込有町 & $\begin{array}{l}\text { 鎌倉、湯島、代々木、 } \\
\text { 駒込百姓地 }\end{array}$ & $\begin{array}{l}\text { 1207, 1627, 1682、 } \\
1692\end{array}$ & 1718 & & 古跡年貢地475坪 & & & 京都東本願寺 \\
\hline 20 & & 教元寺 & 浄土真 & 駒込富士前町 & 日本橋 & 不詳 & 1627 & & $\begin{array}{l}\text { 麟祥院領古跡年貢地396坪 } \\
\text { 内除地16坪町並抱添地 } 49 \\
\text { 坪門前アリ }\end{array}$ & & & 浅草本願寺 \\
\hline 21 & & 長源寺 & 浄土真 & 駒込富士前町 & 練馬、神田御茶/水 & 1612 & 1705 & & $\begin{array}{l}\text { 麟祥院領古跡年貢地 } 544 \text { 坪 } \\
\text { 海坪添地 }\end{array}$ & & & 浅草本願寺 \\
\hline 22 & (0) & 西善寺 & 浄土真 & 駒込三ヶ家町 & 本郷金助町 & 1616,1628 & 1683 & & 麟祥院古跡年貢地 380 坪 & & & 京都東本願寺 \\
\hline 23 & & 真浄寺 & 浄土真 & 本鄉追分 & 神田連雀町、本郷金助 & 1613,1648 & 1761 & & 古跡借地1000坪 & & & 京都東本願寺 \\
\hline 24 & - & 吉祥寺 & 曹洞 & 駒込浅嘉町 & 和田倉門、神田駿河台 & 1458.1591 & 1657 & & $\begin{array}{l}\text { 拝領地、御朱印地寺中 } 4 \text { 子 } \\
\text { 院 }\end{array}$ & 官7427坪 & $\begin{array}{l}\text { 民学寮地1332坪畑 } \\
\text { 3841坪学寮元敷地 } \\
\text { 421坪 }\end{array}$ & 上野永源寺 \\
\hline 25 & $\bullet$ & 高林寺 & 曹洞 & 駒込浅嘉町 & 神田、本郷湯島台 & 1596 & 1657 & & 拝領地6165坪 & 官1579坪 & $\begin{array}{l}\text { 民宅地349坪畑532 } \\
\text { 坪 }\end{array}$ & 武蔵忍集福寺 \\
\hline 26 & (2) & 養昌寺 & 曹洞 & 駒込浅嘉町 & 湯島 & 1722 & 1683 & & 拝領地621坪年貢地133坪 & & & 今戸慶養寺 \\
\hline 27 & $\bullet$ & 江岸寺 & 曹洞 & 駒込片町 & 神田、湯島 & $1596 、 1604$ & 1657 & & $\begin{array}{l}\text { 境内拝領地2609坪+門前田 } \\
\text { 地780坪 }\end{array}$ & 1068坪 & $\begin{array}{l}\text { 民有地畑646坪,願 } \\
\text { 中 }\end{array}$ & 駒込高林寺 \\
\hline 28 & $\square$ & 大円寺 & 曹洞 & 駒込片町 & 神田柳原 & 1624 & 1649 & & 境内4032坪+門前43坪 & 官1528坪 & & 上州清柳茂林寺 \\
\hline 31 & & 大林寺 & 曹洞 & 本楖追分 & 下谷、白山 & $1615-24,1653$ & 1719 & & 古跡年貢地2924坪 & 民3105坪 & & 駒込高林寺 \\
\hline 32 & & 円林寺 & 天台 & 駒込浅嘉町 & & & & 大正後 & 拝領地272坪 & $\begin{array}{l}\text { 官198坪(払下願中) } \\
\text { 墓地43坪 }\end{array}$ & 民74坪 & 上野東谛山 \\
\hline 33 & a & 南谷寺 & 天台 & 駒込浅嘉町 & 現在地 & 1628 & & & な & 官474坪墓地60坪 & 民宅地81坪 & 上野東㕡山 \\
\hline 34 & घ & 世尊院 & 天台 & 駒込千駄木町 & 現在地 & 1695 & & & $\begin{array}{l}\text { 拝領地5300坪内1344坪門 } \\
\text { 前町屋貸地 }\end{array}$ & 官1549坪 & $\begin{array}{l}\text { 官墓地679坪民畑 } \\
\text { 662坪 }\end{array}$ & 上野東亮山 \\
\hline 35 & $\bullet$ & 大保福寺 & 天台 & 駒込千駄木町 & 湯島 & 1653 & 1657 & & 拝領地4032坪除地8坪 & 官1440坪 & $\begin{array}{l}\text { 官墓地773坪民246 } \\
\text { 坪 }\end{array}$ & 上野東亮山 \\
\hline 36 & a & 大恩寺 & 日蓮 & 駒込御旗町 & & 1624 & & 1925 & 年貢地1230坪 & 民1050坪 & 墓地262坪 & 下総中山法華経寺 \\
\hline 37 & & 円成寺 & 日蓮 & 駒込千駄木町 & 不詳 & & 1684 & 1974 & 除地、年貢地 & & & 安房小湊誕生寺 \\
\hline 38 & & 長元寺 & 日蓮 & 駒込追分町鰻縄手 & 太田家屋敷内 & 1627 & 1662 & & 境内除地1080坪 & 官827坪 & 民墓地 319 坪 & 甲斐身延山久遠寺 \\
\hline 39 & & 法林寺 & 日蓮 & 駒込追分町鰻縄手 & & -1671 & & & 除地、年貢地 & & & 甲斐身延山久遠寺 \\
\hline 40 & & 顕本寺 & 日蓮 & 本郷追分 & 不詳、駒込 & 1631,1692 & 1719 & & 年貢地 466 坪 & & & 陸奥会津妙法寺 \\
\hline 41 & - & 浩妙寺 & 日蓮 & 本郷三ヶ家町 & 太田家屋敷内 & 1628 & & & 境内1295坪 & 官484坪 & 墓地 & 駿河玉沢妙法華寺 \\
\hline 42 & $\bullet$ & 勝林寺 & 臨済 & 駒込追分町鰻縄手 & 湯島 & 1615 & 1657 & 1908 & $\begin{array}{l}\text { 拝領地1160坪添地寄進添 } \\
\text { 地260坪 }\end{array}$ & 官314坪 & 民106坪 & 京都妙心寺 \\
\hline 43 & - & 円通寺 & 臨済 & 騳込片町 & 御茶ノ水 & 1630 & 1657 & & 麟祥寺古跡年貢地1500坪 & & & 京都妙心寺 \\
\hline 44 & & 竜光寺 & 臨済 & 駒込土物店新道 & 新宿矢来 & 1632 & 1656 & & $\begin{array}{l}\text { 古跡拝領地3600坪持添年 } \\
\text { 貢地18坪 }\end{array}$ & 官1699坪 & 民畑1820坪 & 京都東福寺 \\
\hline 45 & (2) & 德源寺 & 臨済 & 下駒込村 & 湯島妻恋坂 & 1630 & 1684 & & 麟祥院古跡年貢地1251坪 & & & 京都妙心寺 \\
\hline 46 & $\bullet$ & 養源寺 & 禅宗(臨) & 駒込千駄木町 & 湯島天神下 & 1616 & 1657 & & 古跡拝領地 3000 坪 & 官564坪 & 民畑849坪願中 & 京都妙心寺 \\
\hline
\end{tabular}

寺地は一部を残して消滅している。駒込地区には、前述した四軒寺 町が確認でき、 3 浄土宗蓮光寺、 25 曹洞宗光林寺、35 天台宗大保福寺、 46 臨済宗養源寺など大火後に湯島から移転した寺院がまとまった場 所に確認できる。さらに太田家屋敷内にも名称は違うが寺院が確認 できる。この地区には、街道沿いに町人町家と御用地があり、水戸家、 太田家の広大な武家地は依然としてある。吉祥寺の近隣には、「田畑」 と「在家」の文字が確認できる。

2-（3）麟祥院、伝通院領について

一方、御府内寺社備考に記載されている寺地の種別（表 1）によれ ば、 2 大運寺、 6 十方寺、 17 浄心寺 (以上浄土宗) 、18 常徳寺、20 教 元寺、 21 長源寺、 22 西善寺 (以上浄土真宗)、 43 円通寺、 45 徳源寺 (以
上日蓮宗）の寺地が麟祥院年貢地あるいは借地となっており、安政 3 年重社地図によると、旧中山道沿いの $9 つ の$ 門前や町人地が麟祥院領、 3 つの町人地や門前が伝通院領と記載されている（図 3)。麟祥院は、 寛永元年 (1624)、臨済宗「報恩山 天澤寺」として湯島に創建し、 春日局の法号により「天沢山 麟祥院」と改号した寺院である（図 1、 2)。御府内寺社備考および寺院明細帳によれば、1634（寛永 11）年 に寺領 300 石の御朱印を择領し、そのうち 100 石は豊島郡柏木村の 百姓地、100 石は駒込村の百姓地であったとある。一方伝通院は、浄 土宗寿桂寺と号し、1415（応永 22）年に小石川に創建され、1603（慶 長 8）年、徳川家康生母の方埋葬につき現在地へ移し再興した。当時、 寺領 830 石の御朱印と多くの未寺を持つ寺院であった。前述のとお 


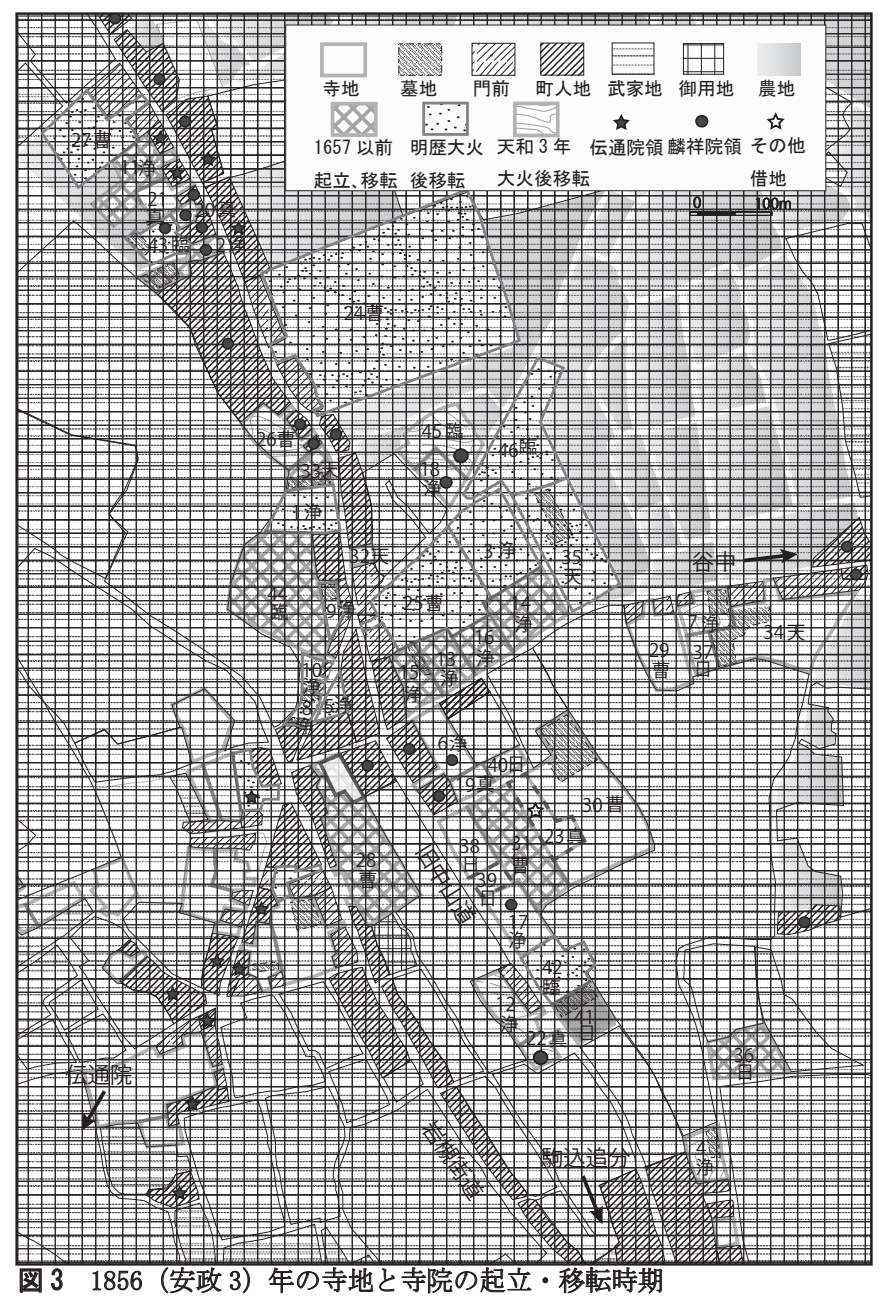

図31856（安政 3）年の寺地と寺院の起立・移転時期
り、麟祥院が駒込に拝領した百姓地は、寛永江戸図および明暦江戸 図にも記載されている、太田家屋敷地の北側周辺の田畑や百姓地を 示すこと、これらの寺院は様々な理由注 1)によって当時田畑であっ た駒込の麟祥院領に移転してきた事がわかる。町人地や門前として、 伝通院領が点在する理由は不明であるが、伝通院の縁起や位置関係 を鑑みると、このあたりが伝通院と麟祥院の領境であった可能性や、 もとは伝通院領であった土地を麟祥院が拝領した可能性などが示唆 される。

\section{3. 明治初期寺領の変化}

\section{3-（1）上知令と境内外区画決定までの経緯}

文京区の寺院は、ほとんどが戦災の被害にあって明治期の史料を残 していない。土地関係資料が残っているまれな例として、4 浄土宗願行 寺）の記事が「文京区史」に取り上げられている ${ }^{14)}$ 。それによれば、 上知令の前年（1870）9月に東京府が寺院の本末寺号、境内坪数などの 調書を提出させており、願行寺では境内除地 1,300 坪、元朱印地除地 山林等なし、滅罪檀家 110 軒、子院の滅罪檀家が合計 102 軒と記して いる。これは御府内寺社備考の記載と合致する。同年 10 月府から測量 に来たが、建物の建坪と税額らしきものを調べただけで土地の間尺は なかった。翌1871 (明治 4) 年 1 月 5 日に上知令注 2) が出、6月には田 畑収納の実績を書出させた。政府は境内（祭典法用に必需な場所）と 民有地を除いた敷地を公収する方針であった。1875（明治 8）年に政府 からの出張調查があり、この時寺側が境内と思っていた土地 63 坪が上 地と決定されたのに驚き、翌明治 9 年に払い下げ願いを提出したが明 治 10 年文書は却下された。さらに明治 12 年に、明治 11 年境内外区画 決定により（境内と）定められた敷地に限り、無償で払い下げになっ たとある ${ }^{14)}$ 。これに対し、寺院明細帳の寺地の種別には「境内官有地

表 2 御府内寺社備考と寺院明細帳の絵図による、四軒寺町の境内の比較

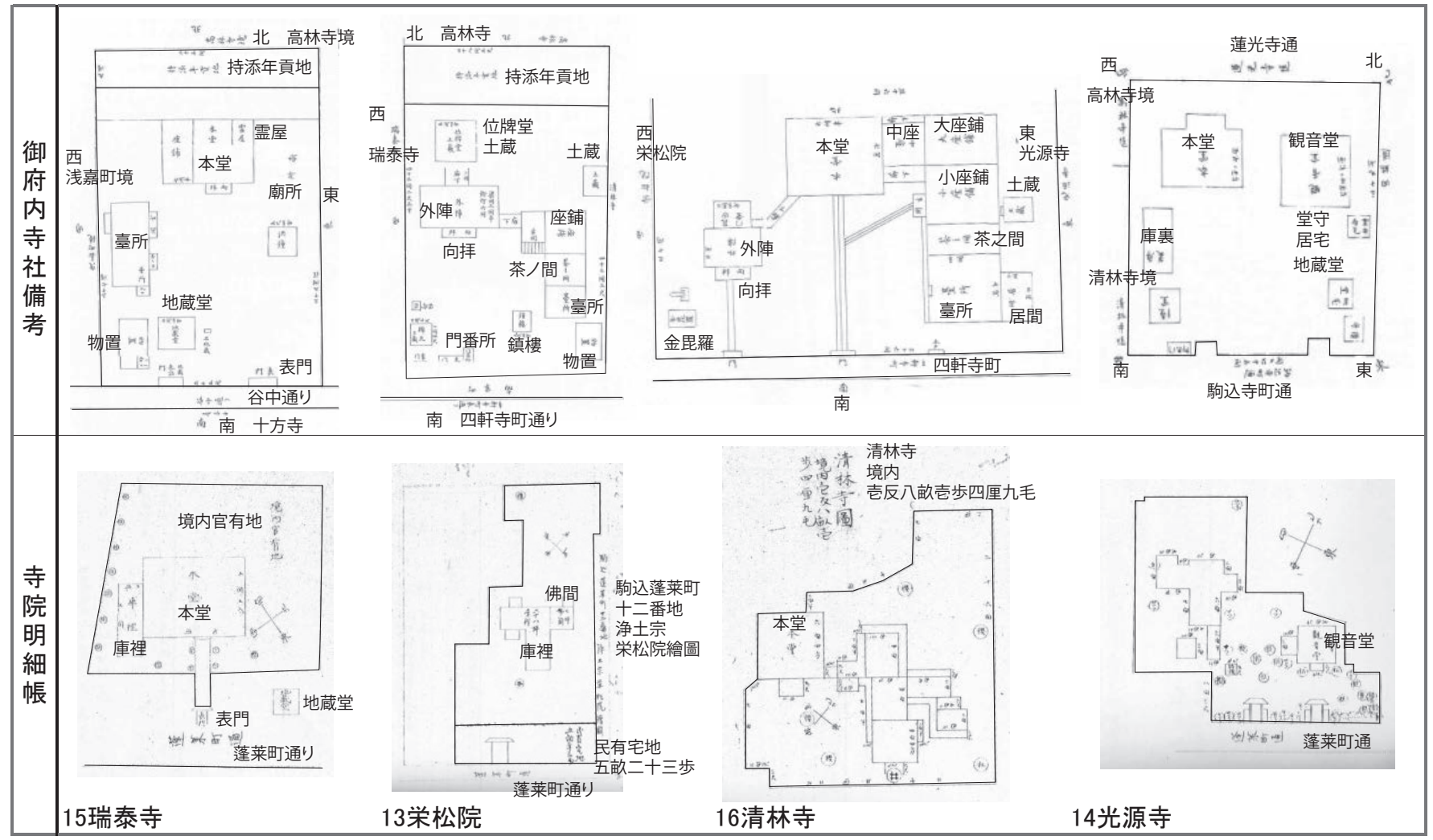


583 坪」と記載されており、その他に境外墓地 397 坪、子院領地約 200 坪があったことがわかっている。

本稿で参考とした寺院明細帳の記録は書面の最後に寺院と格上寺院 の住職や要人の署名捺印が記載されており、期日は明治 10 年となって いる 注 ${ }^{3)}$ 。このことから、明治 3 年概要調查、明治 4 年正月上知令と 寺地境内外区別注 4) と建物調查、明治 8 年現地調查と境内外境の告示、 明治 10 年に記録の提出要請と提出 ${ }^{15)}$ 、明治 11 年境内外の決定、明治 12 年以後に境内官有地払下げなどの処分という経過がよみとれる注5)。 その間の土地関連の動きをみると、明治 2 年沽券状改正 ${ }^{\text {注 }}$ )、明治 4 年 7 月廃藩置県、同年 8 月朱引外区改正、明治 5 年 2 月地券発行、明治 6 年地租改正とあわただしい。ちなみに、明治 6 年に沽券図 ${ }^{* 4}$ が作成さ れていることから、これは沽券状改正、地券発行後の記録であること がわかる。

3-（2）寺院明細帳による境内外区別について

ここで、寺院明細帳に掲載されている境内図から境内と官・民の種 別をプロットした地図を作成した（図 4)。ちなみに、境外については、 書面に官・民の区別と面積が記されている場合があるが、境外につい ては配置図にほとんど記載されていないため、位置が不明な事例が多 数ある 注 7)。まず、御府内寺社備考による寺地の面積と寺院明細帳に記 載されている境内・外の面積を比較すると、1 定泉寺、5 潮泉寺など、 境内官・民有地と境外民有地を合計するとほぼ江戸期の寺地面積と同 等である寺院は他に 14 光源寺、 31 大林寺、 32 円林寺、 36 大恩寺、 38

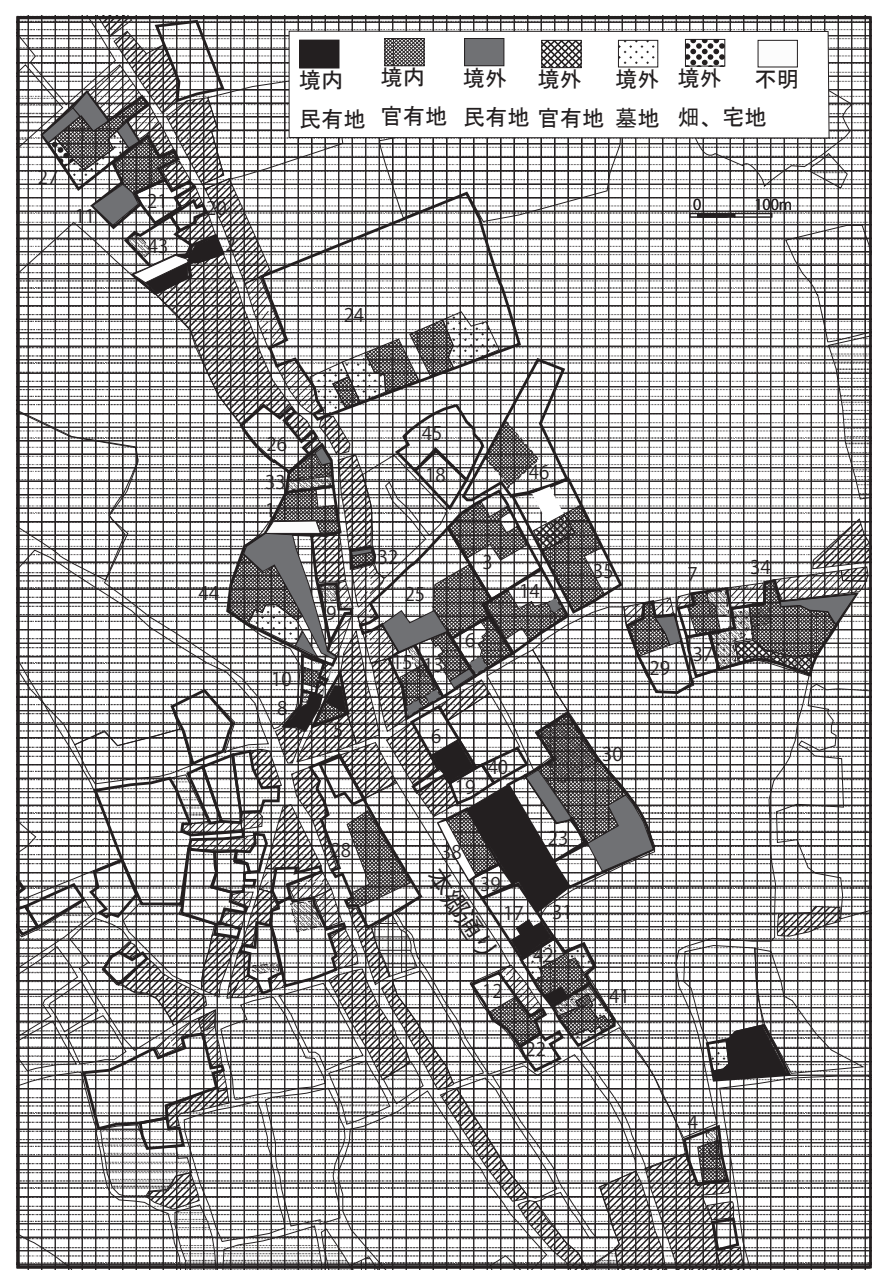

図 41877 年寺院明細帳による寺地の種別
長元寺の 7 ケ寺と数少ない。このうち、31 大林寺と 36 大恩寺は江戸期 に寺地全域が年貢地である。大林寺の寺院明細には、「一. 境内 但シ 民有地券状之儀八大林寺名受二テ貢租モ同寺ヨリ上納」とあり、明治 5 年地券状が発行されて地税も納めたので民有地である、ということが わかり、しかも敷地全域が境内と認められている。境内に民有地を有 寸る寺院はその他に 2 大運寺、 6 十方寺、 8 正念寺、17 浄心寺などがあ るが、いずれも江戸期に年貢地であった面積と同等である。境外に民 有地を有する寺院で、江戸期に拝領地だった寺院については、29 總禅 寺の記載「一. 境外 但民有地 是八当住職木村明禅自費開墾払下券 状之儀八名受ニテ貢租モ同寺ヨリ上納」とあり、自費開墾の労苦を訴 えて払下を受け、地税を収めたことが記されている。また、27 江岸寺 の記載「一. 境内外 但民有地 是八明治十年四月中地券御下渡出願 中」などのように、払下げ出願中であることが記載されている例もある。 一方、境内外に民有地を有しない寺院は 4 願行寺、 7 専念寺、 9 天栄寺、 10 徳性時、12 正行寺、 28 大円寺、 41 浩妙寺で、その多くが江戸期の 寺地が择領地だった寺院である。

\section{3-（3）四軒寺町寺院の境内外区別について}

さらに、明暦江戸図でも確認された四軒寺町の 4 ケ寺（15 瑞泰寺、 13 栄松院、16 清林寺、14 光源寺) について、1826（文政 9）年御府 内寺社備考と 1877 (明治 10）年寺院明細帳の配置図を比較し、境内 外取調べ後の境内の範囲についてさらに詳細な考察を行う（表 2)。 これら 4 寺院を特に取り上げる理由は、前述のとおり由緒がはっき

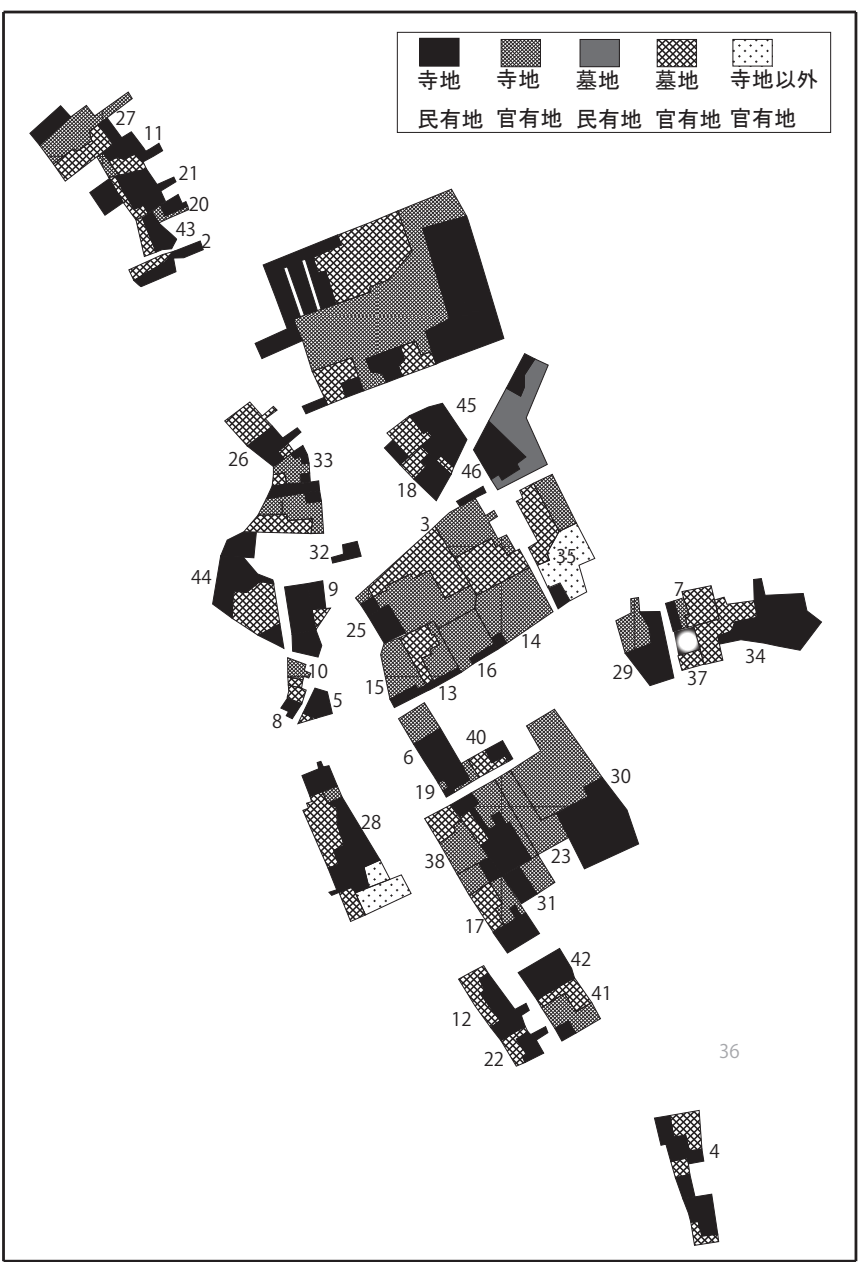

図 51917 年地籍地図・台帳による寺地の種別 


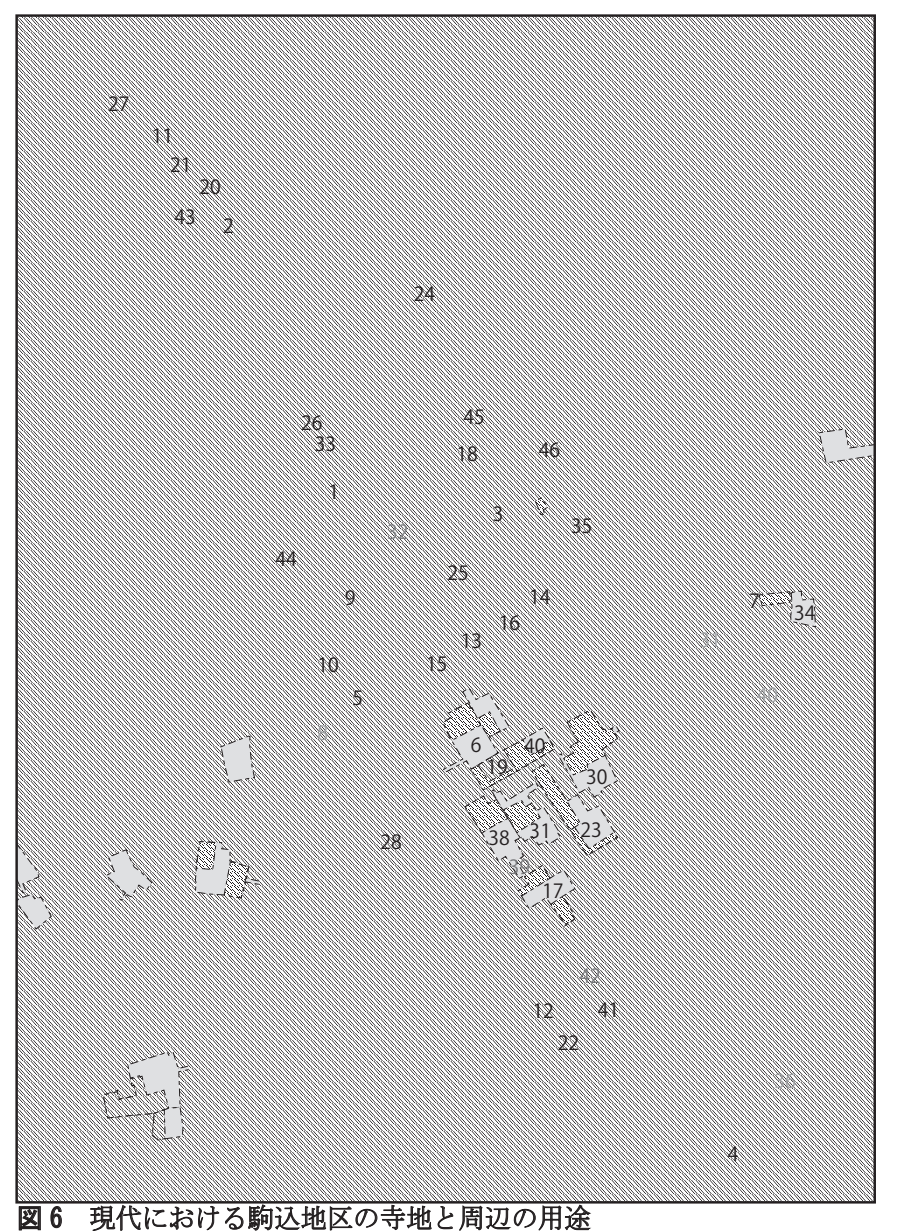

りしていること、これらの寺院が隣接する場所は街区のほぼ全体が 寺地であるため、接道や寺院境界によってより正確な形状把握が可 能なことである。まず、御府内寺社備考の配置図を見ると、四軒寺 前の通りの名称が、「谷中通り」、「四軒寺町通り」、「駒込寺町通」と 様々であることから、当時、町や通りの名称が複数あったことがわ かる。1873（明治 6) 年地租改正の前後明治 $5 \sim 7$ 年にわたって武家 地に町名がつけられたことから ${ }^{16)}$ 、通りを挟んだ太田家敷地に駒込 蓬莱町という名称がついたため、通りの名称が統一されたと推測さ れる。本堂や付属屋の位置をみると、16 清林寺以外は江戸期の建物 配置が全面的に変化している。寺院明細帳の 15 瑞泰寺境内は、江戸 期扯領地の約半分となっており、表門の位置などから街道沿いの寺 地が境内から除外されていることがよみとれる。南東には地蔵堂が あるが境内と認められなかったことがわかり、北側に民有地注 ${ }^{8 ｝ \text { （江 }$ 戸期に持添え年貢地）があると推測できる。また 13 栄松院は、明細 帳の境内図西側に記載されている薄い線が江戸期の寺地境界である う。江戸期は择領地 1080 坪持添年貢地 139 坪、明細帳は境内官有地 541 坪境外民有地 183 坪注 ${ }^{9)}$ とあり、民有地は江戸期の年貢地よりも 広い。境内は瑞泰寺と同様、江戸期の拝領地のほぼ半分の面積となっ ている。境内外区別について、同様な面積の配分が、16 清林寺、 27 江岸寺など他の多数の寺院にもみられ、境内が据領地の約半分以下 でかつ官有地となっている寺院は表 1 中に 18 ケ寺ある。実際に、13 栄松院、16 清林寺、 14 光源寺の境内境は、本堂を含めるために不自 然な凹凸があり、境内の領域をできるだけ切り詰めようとした意図 がよみとれる。

\section{4. 明治以降の寺地の変化}

4-（1）大正元年地籍地図による、明治期の変化

明治 12 年以降の官有地払下げなどによる寺地の変化は、大正元年地

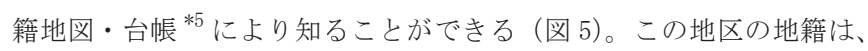
寺地民有地、寺地官有地、墓地民有地、墓地官有地、寺地以外（学校施設） の種別があり、例外として個人名義の寺地（37 円成寺）がある。

まず、図 4 および図 5 を比較しながら、明治期に境内官有地が払下 げによって民有地に変化している事例に着目寸る。特に顕著な例は、 24 吉祥寺子院、34 世尊院、44 竜光寺、46 養源寺などの寺院で、かつ ての境内官有地がすべて民有地になっている。このように、境内官有 地あるいは境外の上地された敷地が民有地に変化している寺院は 12 ケ 寺あり、一方、境内官有地が官有地のままである寺院は、 3 連光寺、 13 栄松院、14 光源寺、15 瑞泰寺、16 清林寺など、表中に 14 ケ寺ある。 次に境外官有地が民有地に変化している寺院では 34 世尊院が顕著であ る。また対象範囲内で民有地を全く持たない寺院は 38 長元寺のみであ る。さらに墓地領域の変化をみると、墓地の位置と面積がほとんど変 わっていないか、もしくは明治初期の境外がそのまま墓地になってい る寺院は、 1 定泉寺、 2 大運寺、 27 江岸寺など 8 ケ寺あり、位置がもと のままで墓地面積が拡張している寺院は 35 大保福寺、34 世尊院、38 長元寺、 44 竜光寺など 7 ケ寺みられる。以上のことから、明治初期の 境内官有地は約半数が払下げられ、境外として上地された敷地につい ても、随時払下げなされたことがわかる。

\section{4-（2）現代の寺地と周辺の用途について}

明治から昭和初期にかけて、この地区から移転した寺院は 6 ケ寺、 昭和後期に移転した寺院が 1 个寺有り、現存寸る寺院は 39 ケ寺である。 寺地に係わる政策の経過を概観すると、まず 1939 （昭和 14）年国有境 内地処分により、一部の国有境内地（官有地）が譲与や払下げを受け たが 1943 （昭和 18）年の開戦により中断、戦後 1947（昭和 22）年第 2 次境内地処分法による審査が開始されて 1953 （昭和 28）年に終了した 17)。さらに1967（昭和 42）年境内地普通財産の処理についての告示に より、寺地の運用を促す結果となった注 ${ }^{10)}$ 。前述の通り、この地区は 戦災により壊滅的な被害を受けたため土地に関する詳細な資料が残っ ていないが、広範囲な区画整理が行われなかったため、街路や街区には、 江戸期の主要な道筋と概形が残っている。

そこで、1999 年住宅地図 ${ }^{* 6}$ と現地調查および航空写真により、現代 の寺地と墓地、住宅、高層マンション、公共施設などの用途をプロッ トした地図を作成し、寺地の変化についての比較検討を行った（図 6)。 まず、寺地が大正元年の規模とほぼ同じである寺院は、6 十方寺、10 徳性寺、14 光源寺、40 顕本寺、4 3 円通寺などがあげられる。特に 6 十 方寺や 10 徳性寺は、街道沿いに江戸期の町人地（門前）の形状も維持 されている。一方、34 世尊院では寺地が大幅に縮小して宅地となって おり、35 大保福寺、25 高林寺、28 大円寺は、寺地が学校施設用地に変 化している（駒込学園中学・高等学校、区立駒本小学校、都立向ヶ丘 高校)。また、13 栄松院は、寺院明細帳に記された境内の形状を維持し ており、この街道沿いに門前町屋があったことがわかる。次に、大正 期と墓地の位置を比較すると、11 天然寺、20 教元寺など墓地が消滅し た寺院を除き、ほとんどの寺院は墓地の位置に変化がない。6 十方寺、 14 光源寺、15 瑞泰寺、16 清林寺では寺地官有地に墓地が形成されてい るが、明治初期に境外だった領域である。例外として、4 願行寺は明治 と大正期の境内官有地に墓地が移動している。さらに、14 光源寺、21 

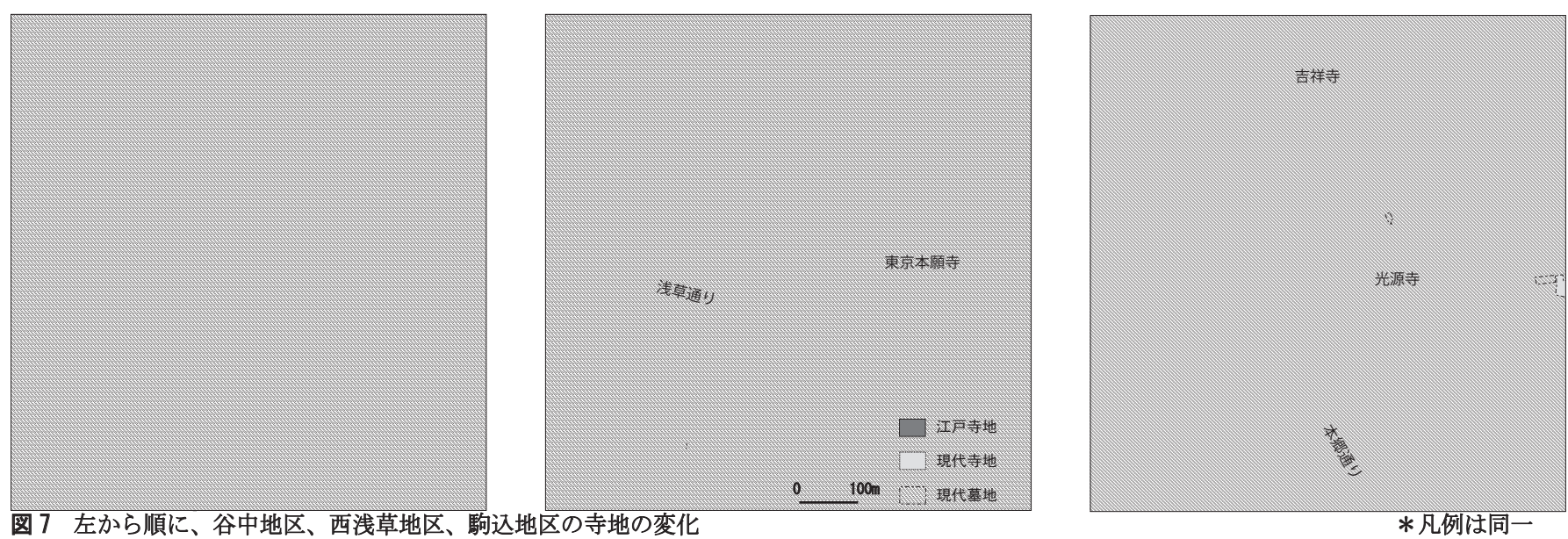

長源寺、 24 吉祥寺、 43 円通寺など複数の寺院では、墓地領域が大幅に 拡大している。寺地自体は縮小していることから、境内地の宅地化と ともに、墓地の需要に答え、新規墓地としての運用がなされているこ とがわかる。最後に、現地調查により寺地に近接して建つ五階建て以 上の高層マンションをプロットした。寺地に隣接する例として、1 定 泉寺、 4 願行寺、 6 十方寺、12 正行寺、 21 長源寺、 34 世尊院、19 尊西 寺が顕著であり、中でも 12 正行寺、19 尊西寺、34 世尊院はマンショ ンは墓地に接している。これらのマンションは主要道路に面しており、 裏のベランダから墓地を望む状況であることがわかる。本郷通り沿い の寺院をみると、寺地が長距離にわたり道路と接している寺院は 38 長 元寺のみで、他の寺院は狭小な参道により接道している状沉である。

\section{5. まとめ}

\section{5-（1）駒込地区について}

以上の研究により得られた知見と考察をまとめる。

(1)駒込地区には、明暦大火以降に神田、湯島、本郷などごく近隣から 移転した寺院が数多い。江戸後期には麟祥院領が 9 ケ寺あり、もと は麟祥院領だった寺院が他にも多数あると考えられる。

(2)明治初期境内外取調べの結果、境内が江戸期拝領地の半分以下となっ ている寺院が 18 ケ寺と多いうえ、本堂を境内に含めるために不自然 な凹凸のある境界線がみられることなどから、境内地を切り詰める 意図があったと推測される。

(3)寺院明細帳の記録によると、境内外取調べの結果、民有地と認めら れたのは、江戸期の年貢地および明治 5 年に地券が発行された土地 と、上地の後に自費開墾の労を訴えて払下げを受け地税を納めた土 地である。

(4)大正期の地籍から、境内官有地がすべて民有地となっている寺院は 4 ケ寺あり、一部が民有地化している寺院が 12 ケ寺ある一方、官有 地のままである寺院が 14 个寺ある。民有地を全く持たない寺院はわ ずかに 1 ケ寺であり、明治期に随時払下げがなされたことがわかる。

(5)明治期に墓地の位置が変化していない寺院は、わかる範囲でも 15 ケ 寺あり、そのうち 7 ケ寺は面積が拡大している。もともと明細帳の 配置図に墓地の記載が少ないことから、明治期に墓地の位置はほと んど変化せず面積はむしろ拡大したと考えられる。

(6)この地区は戦災にあったものの大規模な区画整理がなされていない ため、江戸期の主要な道筋が残っている。現況で寺地が大正元年の 規模とほぼ同じである寺院は 5 ケ寺ほどあり、門前町屋の街区の形
状をおおよそ継承している箇所も所々にみられる。しかし一方で、 寺地と接して道路沿いに高層マンションが建つ場所も多く、マンショ ンのバルコニーから墓地を望む状況となっている。

\section{5-（2）谷中地区、西浅草地区との比較考察}

最後に、前稿 2 編（参考文献 1）、2））で行った谷中地区と西浅草地区 の寺地の変遷との比較考察を行う。3 地区の同スケールの地図に、1856 （安政 3）年の寺地、現代の寺地と墓地を重祮合わせた図を作成した（図 7)。まず、前稿でも述べたとおり、谷中地区では、寺地の一部が宅地 化されているが、寺院数は減っておらず、隣り合う寺地と墓地からな る連続した寺町が現存している。特に、元天王寺の寺地が公営墓地（谷 中霊園）になるなど、墓地が寺地全体の半分以上の領域を優に占めて いる。それに対して西浅草は、江戸期には付近一帯が連続した寺地で あったにも関わらず、谷中地区とは対照的に、寺院数と寺地が共に激 減している。現在は、区画整理された街区の中央に寺地が孤立して残 存している状況である。そして駒込地区では、江戸期の町人地・門前 が寺地まで拡大して宅地化し、武家地は公共施設用地（学校）や私有 地（宅地）となった状況で、江戸期の寺地はある程度のまとまりをも ちつつ分散している。全体的には寺地が減少しているが、境内の場所 が変化せずに隣り合う寺院も数多く、まとまった寺地と墓地が確保さ れている。

* 本研究は、文部科学省科学研究費補助金・基盤研究 (C) (課題番号 21560670）の助成を受けて行なった研究の一部である。

\section{参考文献}

1）渡邊美樹 : 台東区谷中地区の寺地の変遷，日本建築学会計画系論文集 第 76 巻 第 669 号, pp. 2255-2262, 2011. 11

2) 渡邊美樹 : 台東区西浅草の寺町の変遷, 日本建築学会計画系論文集 第 78 巻 第 685 号, pp. 715-723, 2013.3

3）鈴木昌雄 : 初期の江戸における町の変遷と寺院の移転, 封建都市の諸問題 - 日 本の町 II -, 雄山閣 , pp. 97-112，1959 鈴木理生 : 千代田区の歴史，東京ふるさと文庫 5, 名著出版， 1978 鈴木理生 : 幻の江戸 100 年, ちくまライブラリー 57 , 筑摩書房, 1991 鈴木理生 : 江戸の都市計画，三省堂，1988

4）日塔和彦 : 江戸御府内寺院の全体的把握 - 『御府内寺社備考』研究 ( I ) - , 建 築史の鉱脈, 大河直躬先生退官記念論文集刊行会, pp. 171-198, 1995 日塔和彦:『御府内寺社備考』からみた江戸の寺院, 年報都市史研究, 宗教と都市, 山川出版社, pp. 3-18, 1998

5）伊藤毅：都市の空間史，吉川弘文館，2003

6）吉田伸之：巨大城下町江戸の分節構造, 山川出版社, 1999

7）伊坂道子，鈴木博之他 6 名：増上寺旧境内地区歴史的建造物等調査報告書，境 内研究事務局, 2003.7 
8）港区教育委員会：三田寺町の建築，2009.3

9）光井涉 : 近世寺社境内とその建築, 中央公論美術出版, 2001

10）国立国会図書館閲覧部：寺社書上旧幕府引継書目録第 1 冊，1960

11）御府内寺社備考全 7 冊（1828，29）, 名著出版，1986, 87

12) 東京府：寺院明細帳 - 本郷区 文部省用箋、明治 18 (1885), 東京都公文書館 所蔵

13）本郷仏教会：本郷の寺院－街と寺詩 -, 1979

14）文京区役所：文京区史 巻 3, pp. 907-910，1968

15）国文学研究資料館史料館編：社寺明細帳の成立, 名著出版, 2004 年

16）土方晉：江戸時代の江戸の税制と明治 6 年地租改正公布，税務経理協会, 2004 年

17）大蔵省財務局：社寺境内地処分誌, 1954.4

\section{参考地図}

*1 吉原健一郎, 俵元昭（監修）：江戸 明治 東京重ね地図, APP カンパニー, 2004.4

*2 寛永江戸全図, 之潮, 2007. 12

$* 3$ 明暦江戸大絵図, 之潮, 2008.5

*4 東京府地券課：沽券図, 東京都公文書館蔵, 1874

*5 地籍地図・地籍台帳 (東京), 東京市区調査会, 1989.3

*6 はいまっぷ台東区住宅地図, セイコー社, 1999

\section{注}

注 1）例えば 20 教元寺は、日本橋にあった境内地が御用地となり替地を豊島郡 板橋に下附されたが、不便な場所であったためほかに土地を求め、八丁堀辺 に 5 年間仮住居した後に本郷麟祥院百姓年貢地を買い求めた。22 西善寺は、 本郷丸山から金助町に移転、さらに 1683 年に春日の局の要請によって駒込に あった春日局の御朱印地に移転した（参考文献 13，p. 118，284）。

注 2）西暦 1871 年正月 5 日、「社寺ノ所有地 収メテ、府藩縣二屬ス」、東京市 史稿 市街篇 第 51 巻, p. 759
注 3）寺院明細帳は明治 18 年発行と記されているが、各寺院の記録書最後には 寺院や格上寺院の住職による署名捺印があり日付は明治 10 年となっているた め、記載内容は明治 10 年として扱った。

注 4）「太政官府藩縣二令シテ寺地ノ境内 7 定メ、境外地八 6 年間ノ税額 セシム」、明治 4 年 5 月 24 日、詳細を要約すると、現在の境内を除き上地す るにあたり、境内外を定め境外（民有地）については不毛の地といえども墓 所を除いて 6 年の税を課す、東京市史稿 市街篇 51 巻 P. 988, 9

注 5）御府第十九号 $7 以$ 明治十一年五月官有地境内外区画決定之分二限り無代価 ニテ民有地二御下渡被成下

注 6)「令シテ、沽券状ヨ改正シ、同時ニ六尺間ヨ用セシム」、明治 2 年 5 月 17 日、 詳細を要約すると、町屋敷の譲渡が煩雑に行われており町や地所名が相違し ているため従来の沽券状を一切廃止して、別紙雛形により提出すること。東 京市史稿 市街篇 50 巻 P. 754

注 7) 図 5 の地図の道路と敷地境界は基本的に 1856 年重社地図を使用しているが、 寺地の境界については明治 6 年沽券図により若干の修正を行なった。寺院明 細帳の配置図は、敷地形状がかなり簡略化されているうえ、境内地を記すの みで寺地全体の記載がほとんどない。寺院明細帳の境内図をプロットするに あたっては、御府内寺社備考に記載されている表門、接道、方角を敷地形状 を参照しながら、御府内寺社備考の敷地面積と明細帳記載の面積割合を相対 的に検討して記載した。配置図記載の寸法などによる詳細な照合は行ってい ない。

注 8）一. 民有地 八畧廿二歩 但券状瑞泰寺名受貢租モ亦同寺ヨリ上納

注 9）一. 宅地 五畧二拾三歩 但券状栄松院名受貢税モ同院ヨリ上納

注 10）社寺境内地などとして使用されている普通財産の処理について、大蔵省国 有財産局告示第 1196 号、昭和 42 年を参照しながら、御府内寺社備考の敷地 面積と明細帳記載の面積割合を相対的に検討して記載した。配置図記載の寸 法などによる詳細な照合は行っていない。

（2013年 8 月 1 日原稿受理，2013年12月 6 日採用決定） 